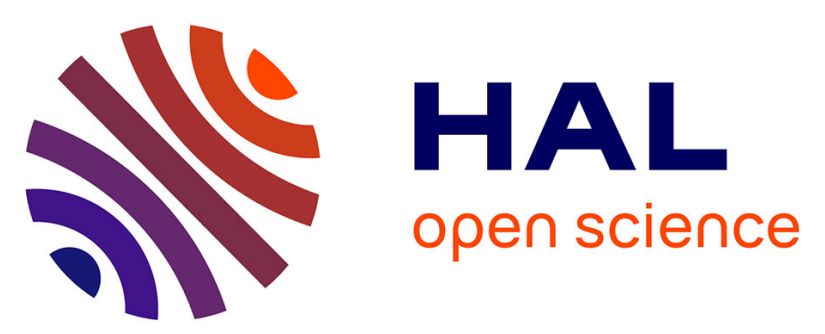

\title{
Changes in histamine and microbiological analyses in fresh and frozen tuna muscle during temperature abuse
} Vangelis Economou, Moira Brett, Chrissanthy Vassilios Papadopoulou, Stathis Frillingos, Tom Nichols

\section{- To cite this version:}

Vangelis Economou, Moira Brett, Chrissanthy Vassilios Papadopoulou, Stathis Frillingos, Tom Nichols. Changes in histamine and microbiological analyses in fresh and frozen tuna muscle during temperature abuse. Food Additives and Contaminants, 2007, 24 (08), pp.820-832. 10.1080/02652030701278321 . hal-00577558

\section{HAL Id: hal-00577558 \\ https://hal.science/hal-00577558}

Submitted on 17 Mar 2011

HAL is a multi-disciplinary open access archive for the deposit and dissemination of scientific research documents, whether they are published or not. The documents may come from teaching and research institutions in France or abroad, or from public or private research centers.
L'archive ouverte pluridisciplinaire HAL, est destinée au dépôt et à la diffusion de documents scientifiques de niveau recherche, publiés ou non, émanant des établissements d'enseignement et de recherche français ou étrangers, des laboratoires publics ou privés. 


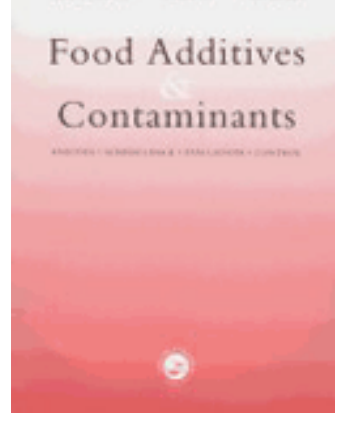

\section{Changes in histamine and microbiological analyses in fresh and frozen tuna muscle during temperature abuse}

\begin{tabular}{|r|l|}
\hline Journal: & Food Additives and Contaminants \\
\hline Manuscript ID: & TFAC-2006-333.R2 \\
\hline Manuscript Type: & Original Research Paper \\
\hline Author: & 04-Feb-2007 \\
\hline Complete List of Authors: & $\begin{array}{l}\text { ECONOMOU, VANGELIS; Medical School, Microbiology } \\
\text { Brett, Moira; CPHLS, Food Safety Microbiology Laboratory } \\
\text { Papadopoulou, Chrissanthy; Ioannina University, Medical School, } \\
\text { Microbiology } \\
\text { Frillingos, Stathis; Medical School Ioannina University, Biochemistry } \\
\text { Nichols, Tom; CPHLS, Statistics Unit }\end{array}$ \\
\hline Methods/Techniques: & Health significance, Microbiology, Quality assurance \\
\hline Additives/Contaminants: & Animal products, Natural toxicants, Process contaminants \\
\hline Food Types: & Fish \\
\hline & \\
\hline &
\end{tabular}

\section{SCHOLARONE Manuscripts}



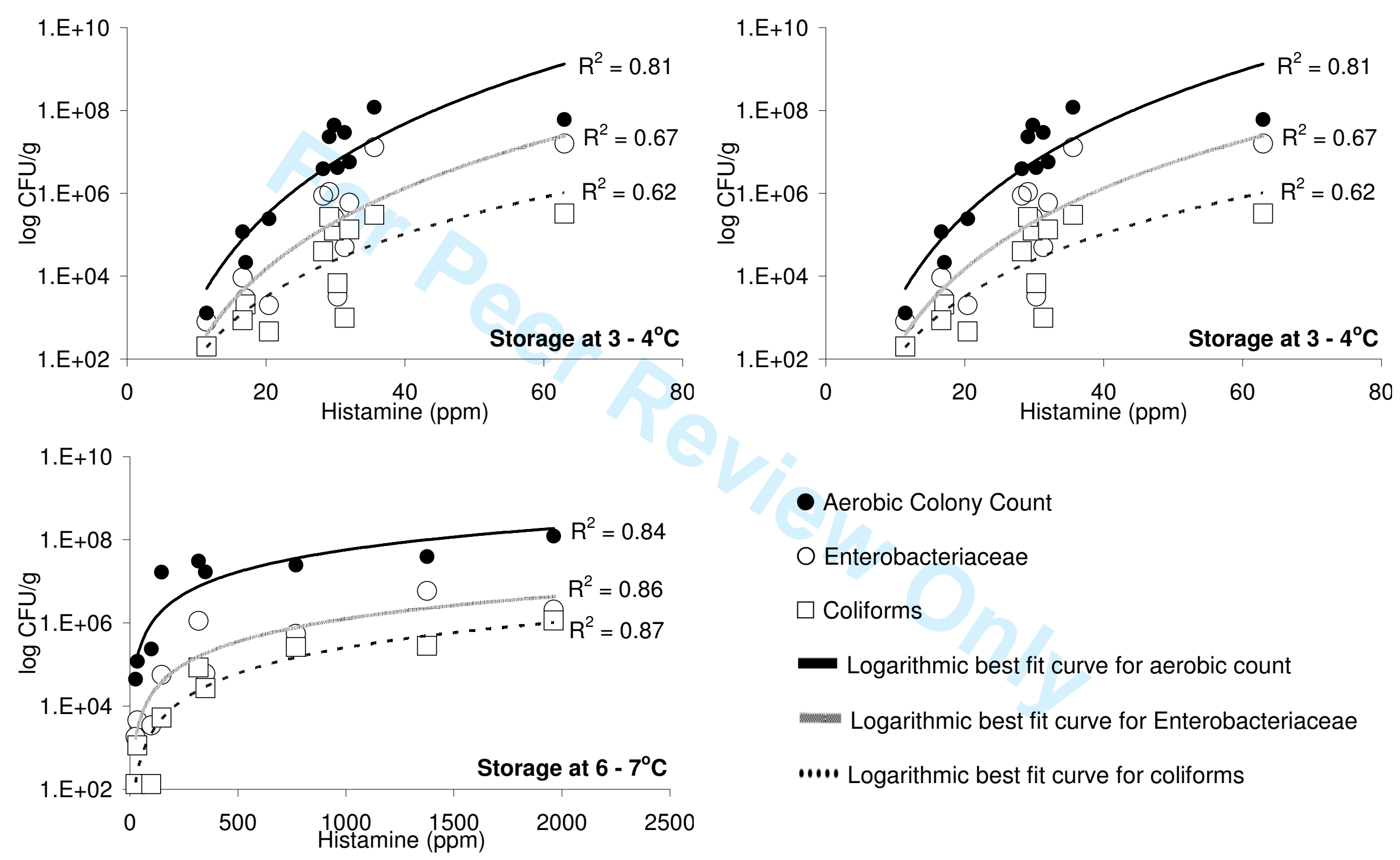

- Aerobic Colony Count

Enterobacteriaceae

$\square$ Coliforms

Logarithmic best fit curve for aerobic count

Logarithmic best fit curve for Enterobacteriaceae

..... Logarithmic best fit curve for coliforms

1 Figure 1. Regression analysis of histamine and Aerobic Colony Counts, Enterobacteriaceae and coliforms 
Table 1

Temperature abuse conditions

\begin{tabular}{|c|c|c|c|c|c|c|c|c|c|}
\hline $\begin{array}{l}\frac{0}{7} \\
\frac{0}{0} \\
\frac{\overline{0}}{\frac{\pi}{2}}\end{array}$ & $\begin{array}{l}\text { 윽 } \\
\text { 응 } \\
\text { 윽 } \\
\text { ஸे }\end{array}$ & 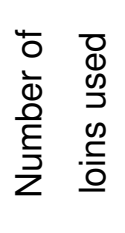 & 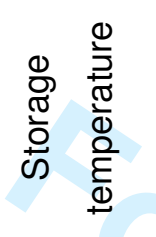 & 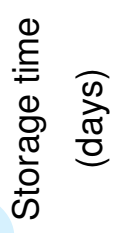 & $\begin{array}{c}\text { Abuse } \\
\text { temperature }\end{array}$ & $\begin{array}{l}\text { Abuse duration } \\
\qquad\left(\text { h day }^{-1}\right)\end{array}$ & Original State & Defrosting procedure & \\
\hline \multirow{4}{*}{1} & Controls (C) & 3 & \multirow{4}{*}{$3-4^{\circ} \mathrm{C}$} & \multirow{4}{*}{7} & \multirow{4}{*}{$20^{\circ} \mathrm{C}$} & 0 & \multirow{4}{*}{ Frozen } & Fridge $\mathrm{T}\left(3-4^{\circ} \mathrm{C}\right)$ for $24 \mathrm{~h}$ & \\
\hline & 1 & 3 & & & & \multirow{3}{*}{2} & & Fridge $\mathrm{T}\left(3-4^{\circ} \mathrm{C}\right)$ for $24 \mathrm{~h}$ & \\
\hline & 2 & 3 & & & & & & Room $\mathrm{T}\left(18-22^{\circ} \mathrm{C}\right)$ for $12 \hbar$ & Formatted Table \\
\hline & 3 & 3 & & & & & & $\begin{array}{c}\text { MW (20 min at defreezing). } \\
\text { Surface } \mathrm{T}=15-18^{\circ} \mathrm{C} \text {, Core } \mathrm{T}=3-5^{\circ} \mathrm{C}\end{array}$ & \\
\hline \multirow{3}{*}{2} & Controls (C) & 3 & \multirow{3}{*}{$0-2^{\circ} \mathrm{C}$} & \multirow{3}{*}{12} & \multirow{3}{*}{$30^{\circ} \mathrm{C}$} & 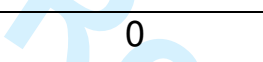 & \multirow{2}{*}{ Fresh } & & \\
\hline & 1 & 3 & & & & & & & \\
\hline & 2 & 3 & & & & & Frozen & Fridge $\mathrm{T}\left(3-4^{\circ} \mathrm{C}\right)$ for $24 \mathrm{~h}$ & \\
\hline \multirow{3}{*}{3} & Controls (C) & 3 & \multirow{3}{*}{$6-7^{\circ} \mathrm{C}$} & \multirow{3}{*}{12} & \multirow{3}{*}{$30^{\circ} \mathrm{C}$} & 0 & \multirow{2}{*}{ Fresh } & & \\
\hline & 1 & 3 & & & & ? & & & \\
\hline & 2 & 3 & & & & 6 & Frozen & Fridge $\mathrm{T}\left(3-4^{\circ} \mathrm{C}\right)$ for $24 \mathrm{~h}$ & \\
\hline
\end{tabular}


Table 2

Histamine concentrations and bacterial counts in tuna loins stored at $3-4^{\circ} \mathrm{C}$ and abused at $20^{\circ} \mathrm{C}$ (histamine (ppm) in average and standard error in brackets, bacterial counts (CFU gr ${ }^{-1}$ ) in average of $\log _{\underline{10}}$ and standard error in brackets).

\begin{tabular}{|c|c|c|c|c|c|c|c|c|c|}
\hline \multirow{4}{*}{$\begin{array}{l}\frac{\infty}{0} \\
\frac{0}{0} \\
0\end{array}$} & Days & $\mathrm{H}^{\mathrm{a}}$ & $A C C^{b}$ & $\mathbf{E}^{\mathrm{c}}$ & $C^{d}$ & $\mathbf{S T}^{\mathrm{e}}$ & SRB $^{f}$ & $\mathrm{LAB}^{\mathrm{g}}$ & PS $^{h}$ \\
\hline & 0 & $11.4(3.3)$ & $3.1(0.1)$ & $2.9(0.2)$ & $2.3(0.1)$ & $<2$ & $<1$ & $<2$ & 2 \\
\hline & 5 & $31(2.5)$ & $5.4(1.7)$ & $3.5(1.1)$ & $1.7(1.2)$ & $3.4(2.4)$ & $1.15(0.8)$ & $3.4(2.4)$ & $5.5(0.9)$ \\
\hline & 7 & $30(6.1)$ & $6.3(1.1)$ & $4(1.2)$ & $2.7(1.9)$ & $4.9(1.6)$ & $<1$ & $3.6(2.6)$ & $5.9(1.5)$ \\
\hline \multirow{12}{*}{ 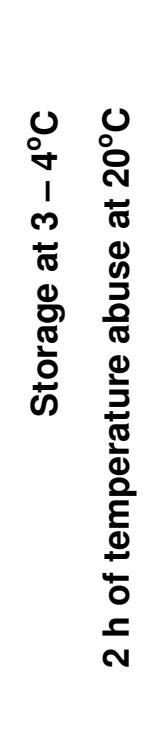 } & \multicolumn{9}{|c|}{ Defrosting at fridge temperature } \\
\hline & 0 & $17.1(0.5)$ & $3.8(0.4)$ & $3.4(0.2)$ & $3.1(0.3)$ & $2.2(0.9)$ & $0.6(0.5)$ & $1.3(1)$ & $2.2(1.1)$ \\
\hline & 5 & $30.3(0.6)$ & $6.2(0.5)$ & $3.2(0.4)$ & $3.2(0.5)$ & $6(0.3)$ & $0.8(0.6)$ & $5.2(0.6)$ & $6.5(0.2)$ \\
\hline & 7 & $29.1(1.7)$ & $6.9(0.5)$ & $5.1(0.6)$ & $4.4(0.7)$ & $6.8(0.2)$ & $0.3(0.3)$ & $5.8(0.6)$ & $7.1(0.5)$ \\
\hline & \multicolumn{9}{|c|}{ Defrosting at room temperature } \\
\hline & 0 & $20.4(0.6)$ & $4.1(0.8)$ & $2.8(0.4)$ & $2.5(0.2)$ & $3.3(0.6)$ & $<1$ & $2.2(1.1)$ & $3.3(1.6)$ \\
\hline & 5 & $32(8.5)$ & $6.4(0.4)$ & $5.1(0.6)$ & $3.3(1.3)$ & $5.9(0.7)$ & $1.4(0.7)$ & $5.4(0.4)$ & $6.4(0.4)$ \\
\hline & 7 & $36(3.5)$ & $8.1(0.1)$ & $6.6(0.4)$ & $3.9(0.8)$ & $6.6(0.6)$ & $<1$ & $6.5(0.5)$ & $8(0.3)$ \\
\hline & \multicolumn{9}{|c|}{ Defrosting using a microwave oven } \\
\hline & 0 & $16.6(3.7)$ & $4(0.8)$ & $3.5(0.4)$ & $2.8(0.2)$ & $1.1(0.9)$ & $<1$ & $1.6(0.6)$ & $3.1(1.5)$ \\
\hline & 5 & $28.2(6.5)$ & $5.4(1)$ & $4.6(0.7)$ & $1.7(1.4)$ & $4.7(1.1)$ & $1.6(0.7)$ & $3.4(1.4)$ & $6.6(0.3)$ \\
\hline & 7 & $63(26.4)$ & $7(0.8)$ & $5.1(1.4)$ & $3.6(1.4)$ & $4.9(2)$ & $0.5(0.4)$ & $4.3(1.9)$ & $6.8(0.7)$ \\
\hline
\end{tabular}

${ }^{\mathrm{a} H i s t a m i n e},{ }^{\mathrm{b}}$ Aerobic colony count $\left(30^{\circ} \mathrm{C}\right),{ }^{\mathrm{C}}$ Enterobacteriaceae, ${ }^{\mathrm{d} C o l i f o r m s},{ }^{\mathrm{e}}$ Staphylococcus spp., ${ }^{\mathrm{f}}$ Sulfite reducing bacteria, ${ }^{\mathrm{g}} \mathrm{Lactic}$ acid bacteria, ${ }^{\mathrm{h}}$ Pseudomonas $\mathrm{spp}_{\mathrm{v}}$ 
Table 3

Histamine concentrations and microbial counts in fresh and frozen tuna loins stored at $0-2^{\circ} \mathrm{C}$ and abused at $30^{\circ} \mathrm{C}($ histamine (ppm) in average and standard error in brackets, bacterial counts (CFU gr ${ }^{-1}$ ) in average of $\log _{\underline{10}}$ and standard error in brackets).

\begin{tabular}{|c|c|c|c|c|c|c|c|c|c|}
\hline & Days & $\mathrm{H}^{\mathrm{a}}$ & $A C C^{b}$ & $E^{c}$ & $C^{d}$ & $\mathbf{S T}^{\mathrm{e}}$ & $S_{R B}^{f}$ & $\mathrm{LAB}^{\mathrm{g}}$ & PS $^{h}$ \\
\hline & 0 & $20.1(18.6)$ & $4.8(0.3)$ & $4(0.3)$ & $2.9(0.3)$ & $3.5(0.1)$ & $1.5(0.3)$ & $3.5(0.1)$ & $3.8(0.3)$ \\
\hline \multirow{13}{*}{ 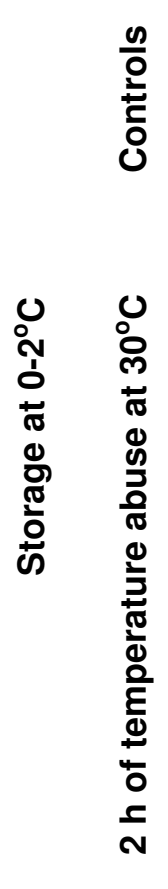 } & 4 & $20.5(2.5)$ & & & & & & & \\
\hline & 8 & $50.7(5.9)$ & $6.8(0.3)$ & $5(0.3)$ & $4.2(0.2)$ & $5(0.7)$ & $1.2(0.2)$ & $5.4(0.1)$ & $5.9(0.1)$ \\
\hline & 12 & $33.5(1.8)$ & $7.4(0.2)$ & $6(0.1)$ & $2.3(1.6)$ & $6.4(0.6)$ & $1.3(0.2)$ & $6.5(0.2)$ & $6.4(0.1)$ \\
\hline & \multicolumn{9}{|c|}{ Fresh tuna } \\
\hline & 0 & $23.3(10.2)$ & \multirow[t]{2}{*}{$5.6(0.3)$} & \multirow[t]{2}{*}{$4.1(0.1)$} & \multirow[t]{2}{*}{$3.5(0.2)$} & \multirow[t]{2}{*}{$4.4(0.5)$} & \multirow[t]{2}{*}{$1.7(0.5)$} & \multirow[t]{2}{*}{$4(0.6)$} & \multirow[t]{2}{*}{$4.6(0.3)$} \\
\hline & 4 & $30.6(6.6)$ & & & & & & & \\
\hline & 8 & $80.9(30.6)$ & $7.1(0.2)$ & $5.2(0.5)$ & $4.2(0.4)$ & $5.5(0.3)$ & $1.6(0.6)$ & $6.2(0.1)$ & $6.3(0.4)$ \\
\hline & 12 & $258.3(79.2)$ & $7.1(0.2)$ & $6(0.6)$ & $3.8(1.6)$ & $6.4(0.4)$ & $2.3(0.2)$ & $6.7(0.3)$ & $6.7(0.3)$ \\
\hline & \multicolumn{9}{|c|}{ Frozen tuna } \\
\hline & 0 & $28.8(3.5)$ & \multirow[t]{2}{*}{$4.8(0.3)$} & \multirow[t]{2}{*}{$3(0.4)$} & \multirow[t]{2}{*}{$2.7(0.4)$} & \multirow[t]{2}{*}{$3.6(0.3)$} & \multirow[t]{2}{*}{$1.7(0.2)$} & \multirow[t]{2}{*}{$3.7(0.2)$} & \multirow[t]{2}{*}{$4.2(0.5)$} \\
\hline & 4 & $50.5(3)$ & & & & & & & \\
\hline & 8 & $24(2)$ & $7.3(0.1)$ & $5(0.2)$ & $4(0.2)$ & $6.6(0.3)$ & $3(0.4)$ & $6.4(0.3)$ & $6.8(0.3)$ \\
\hline & 12 & $32.3(6.4)$ & $7.7(0.2)$ & $5.5(0.1)$ & $4.3(0.3)$ & $7.3(0.5)$ & $3.1(0.2)$ & $7(0.4)$ & $6.7(0.1)$ \\
\hline
\end{tabular}

${ }^{\text {aHistamine, }}{ }^{\mathrm{b}}$ Aerobic colony count $\left(30^{\circ} \mathrm{C}\right),{ }^{\mathrm{c}}$ Enterobacteriaceae, ${ }^{\mathrm{d}}$ Coliforms, ${ }^{\mathrm{e}}$ Staphylococcus spp., ${ }^{\mathrm{f}}$ Sulfite reducing bacteria, ${ }^{9}$ Lactic acid bacteria, ${ }^{\mathrm{h}}$ Pseudomonas spp 
Table 4

Histamine concentrations and microbial counts in fresh and frozen tuna loins stored at $6-7^{\circ} \mathrm{C}$ and abused at $30^{\circ} \mathrm{C}$ (histamine (ppm) in average and standard error in brackets, bacterial counts (CFU gr ${ }^{-1}$ ) in average of $\log _{\underline{10}}$ and standard error in brackets).

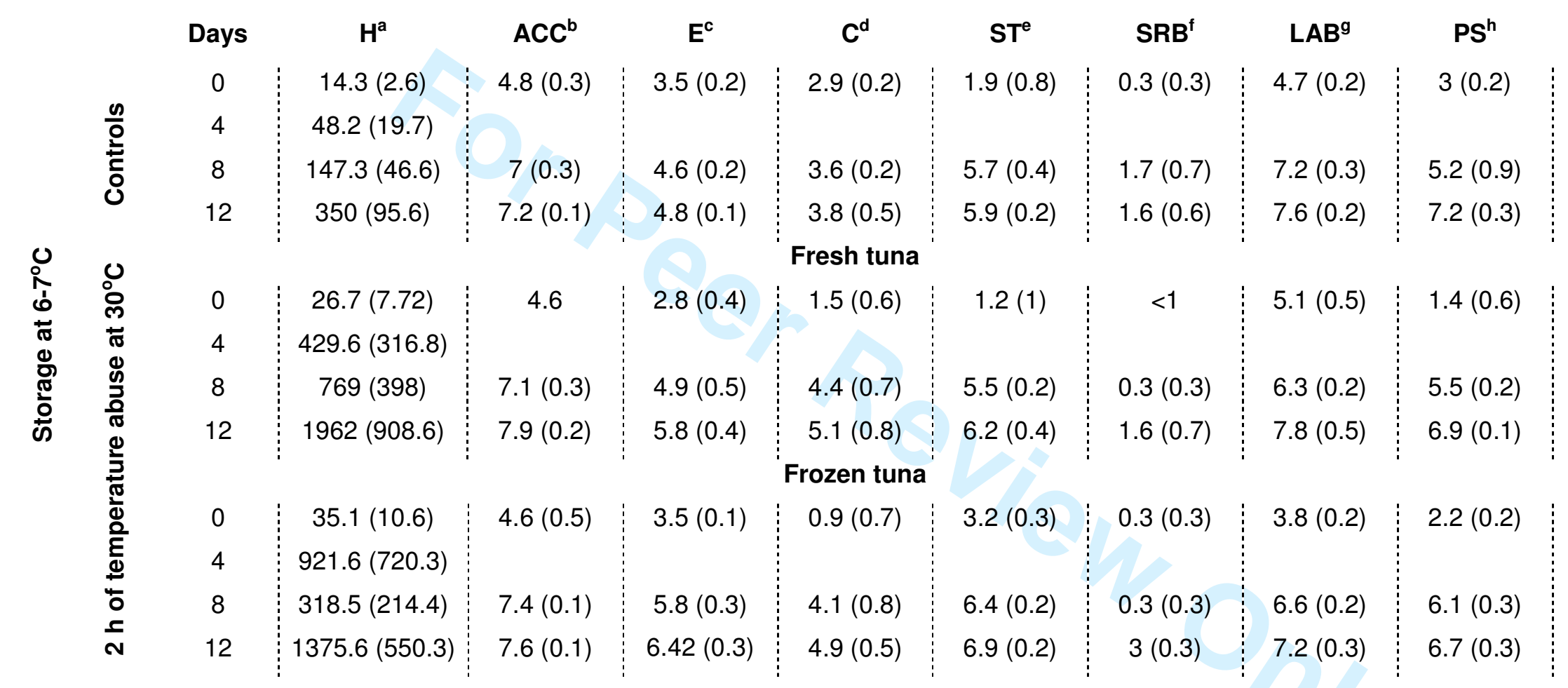

${ }^{\text {a Histamine, }}{ }^{\mathrm{b}}$ Aerobic colony count $\left(30^{\circ} \mathrm{C}\right),{ }^{\mathrm{c}}$ Enterobacteriaceae, ${ }^{\mathrm{d}}$ Coliforms, ${ }^{\mathrm{e}}$ Staphylococcus spp., ${ }^{\mathrm{f} S u l f i t e}$ reducing bacteria, ${ }^{\mathrm{g}} \mathrm{Lactic}$ acid bacteria, ${ }^{\mathrm{h}}$ Pseudomonas spp. 
Table 5

Deleted: 6

Bacterial isolates and histamine concentration in culture supernatants after incubation at $37^{\circ} \mathrm{C}$ for 48 h.

Deleted: Histamine

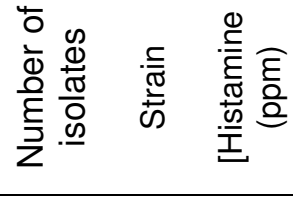

Gram positive cocci

Staphylococcus aureus auricularis

S3

S6 Formatted Table freundii $7-\mathrm{C} 2$

$\mathrm{C} 4$

\section{C6}

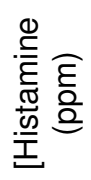

Enterobacter amnigenus aerogenes cloacae

Escherichia coli ES1 ES2

ES3

ES4

Ewingella americana 11 EW1 Hafnia alvei

$\mathrm{H} 1$

Klebsiella

oxytoca

terrigena pneumoniae

Morganellla

Proteus

aquatilis

Salmonella
4

42

19

6

5

2

2
2

0

60 2

0 0
0
0

20 18

3
2

1
76

66

2156 2149 0 0
0 0 20 6875 6296 11 8
0 Pasteurella

Flavimonas epidermidis

1 S2 S5 S4 305

\section{$\underline{\text { hominis }}$}

simulans xylosus

\section{Enterococcus}

Gram negative rods

Burkholderia

Pseudomonas

cepacia ryzihabitans fluorescens

putida

sobriae caviae haemolytica

P3 2
S7 $\quad 1$

S9 0

S10 0

1

S8 1

$\mathrm{S} 130$

S14 0

S15 0

EN1 15 EN2 2404

B1 0

F1 0

P4 1

P1 1

P4 0

P7 0

P9 0

P10 0

$\begin{array}{ll}\text { P5 } & 1 \\ \text { P6 } & 0\end{array}$

P8 0

P11 0

A1 7

A2 0

PA1 0
P2 0
Deleted:

http://mc.manuscriptcentral.com/tfac Email: fac@tandf.co.uk 


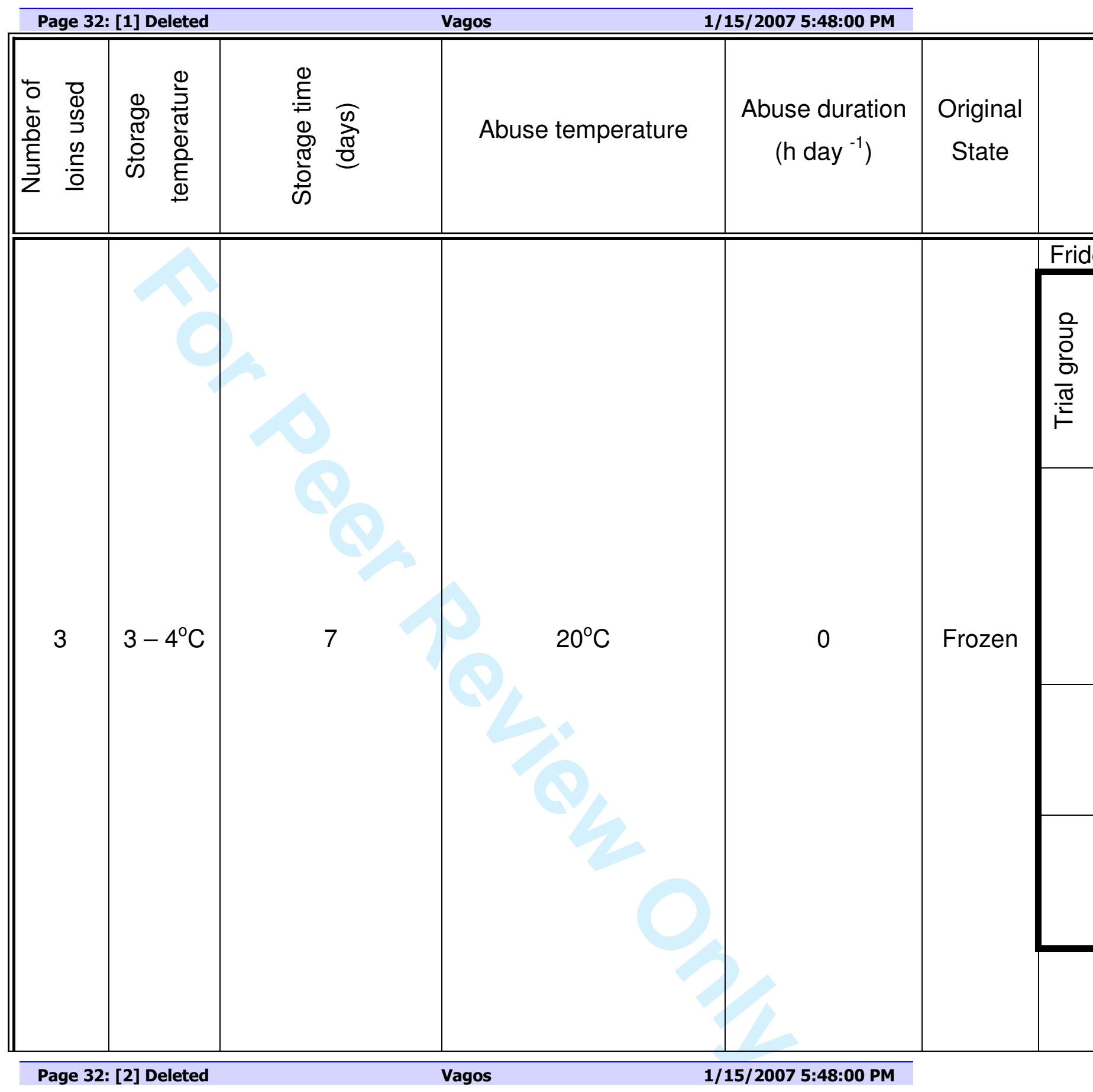




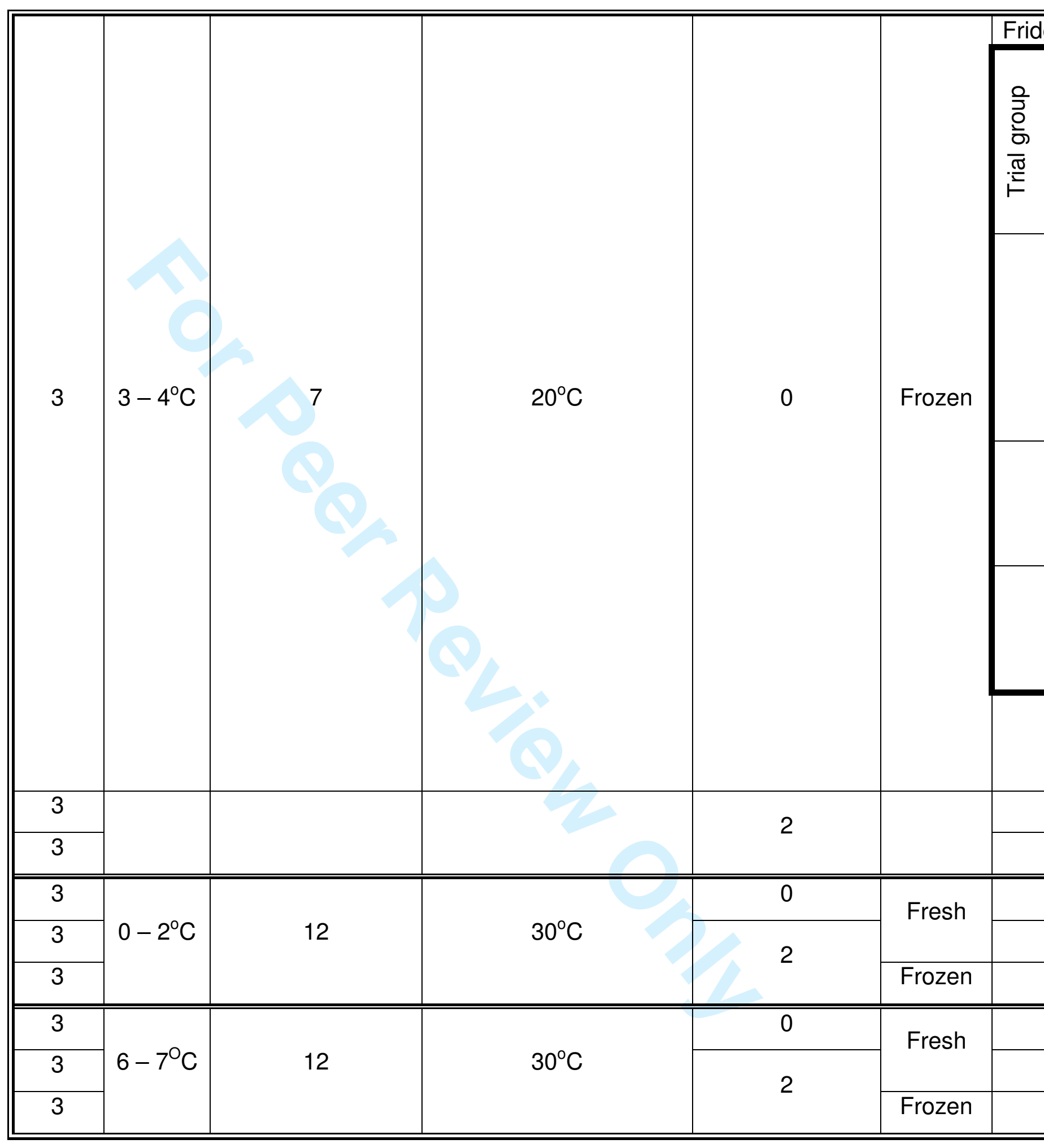

http://mc.manuscriptcentral.com/tfac Email: fac@tandf.co.uk 


\section{Changes in histamine and microbiological analyses in fresh and frozen tuna muscle during temperature abuse}

VAGELIS ECONOMOU1, MOIRA M BRETT², CHRISSANTHY PAPADOPOULOU*1, STATHIS FRILLINGOS ${ }^{3}$, TOM NICHOLS ${ }^{4}$

${ }^{1}$ Food Microbiology Unit, Microbiology Department, Medical School, University of loannina, Ioannina, 45110, Greece

${ }^{2}$ Marine Biotoxins Unit, Food Safety Microbiology Laboratory, Central Public Health Laboratory Service, 61 Colindale Avenue, London NW9 5HT, UK

${ }^{3}$ Biochemistry Department, Medical School, University of Ioannina, Ioannina 45110, Greece

${ }^{4}$ PHLS Statistics Unit, PHLS Communicable Disease Surveillance Centre, 61 Colindale Avenue, London NW9 5EQ

Running title: Histamine and bacterial flora in tuna fish

\section{${ }^{*}$ Corresponding author.}

Chrissanthy Papadopoulou,

Associate Professor, Food Microbiology Unit, Microbiology Department, Medical School, University of Ioannina, University Campus, Ioannina 45110, Greece. Telephone: ++30 2651097592, Fax: ++30 2651097855 and ++32651093563, E-mail: cpapadop@cc.uoi.gr 


\section{Abstract}

2

3 Temperature abuse of tuna (Thunnus alalunga) was carried out in order to assess

4 the histamine build-up in fish processing facilities where fish can be exposed to high

5 temperatures for short periods of time. Histamine production was studied in tuna

6 loins under different storage and abuse conditions. Tuna was stored at $0-2^{\circ} \mathrm{C}, 3-4^{\circ} \mathrm{C}$

7 and $6-7^{\circ} \mathrm{C}$ and abused for $2 \mathrm{~h}$ daily at $20^{\circ} \mathrm{C}$ and $30^{\circ} \mathrm{C}$ for $7-12$ days. Loins abused at

$830^{\circ} \mathrm{C}$ for $2 \mathrm{~h}$ daily, contained potentially toxic histamine concentrations (67-382 mg

$\left.9 \quad \mathrm{~kg}^{-1}\right)$ when stored at low refrigeration temperature $\left(0-2^{\circ} \mathrm{C}\right)$, whereas when stored at 6-

$10 \quad 7^{\circ} \mathrm{C}$ the loins contained highly toxic histamine concentrations $\left(544.5-4156.6 \mathrm{mg} \mathrm{kg}^{-1}\right)$.

11 Lower histamine concentrations (23 to $48 \mathrm{mg} \mathrm{kg}^{-1}$ in loins stored at $0-2^{\circ} \mathrm{C}$ and $124.7-$

$12 \quad 2435.8 \mathrm{mg} \mathrm{kg}^{-1}$ in loins stored at $6-7^{\circ} \mathrm{C}$ ) were observed in temperature abused loins

13 that were initially frozen. An increase over time was observed in most microbial

14 counts tested. Bacteria isolated from the temperature abused loins showed varied 15 ability of histamine production with Morganella morganii, Klebsiella oxytoca, 16 Staphylococcus hominis and Enterococcus hirae being the most active histamine 17 producing bacteria.

18

19 Keywords: Histamine, tuna, storage, temperature abuse, bacteria. 


\section{Introduction}

2

3 Histamine formation in fish is related to the free histidine content of the fish muscle,

4 the presence of bacterial histidine decarboxylases and certain environmental

5 conditions. The production of histamine is largely induced by post-harvest exposure

6 to high temperature of the fish. Temperature enhances the multiplication of bacteria

7 and the bacterial production of histidine decarboxylases. In addition, histidine

8 decarboxylase activity is favoured by the exposure to temperatures higher than $15^{\circ} \mathrm{C}$

9 (Lehane and Olley 2000: Kanki et al. 2007). In general, histamine production is

10 favored by temperatures higher than $5^{\circ} \mathrm{C}$ with an optimum of $20-30^{\circ} \mathrm{C}$ (Kim et al.

11 2000; Lehane and Olley 2000), and by the presence of bacterial species that are

12 prolific histamine producers. Enterobacteriaceae (Morganella morganii, Enterobacter

13 cloacae, Citrobacter freundii, Escherichia coli, Hafnia alvei, Klebsiella pneumoniae,

14 Proteus spp., Serratia macrescens) have been reported to be the most prolific 15 histamine producers (Taylor et al. 1979; Behling and Taylor 1982; Taylor 1986; 16 Klausen and Huss 1987; Ababouch et al. 1991; Rodriguez-Jerez et al. 1994; Emborg 17 and Dalgaard 2006), followed by the lactic acid bacteria (Lactobacillus spp., 18 Carnobacterium spp.) (Taylor 1985; Joosten and Northolt 1989) and Photobacterium 19 spp. (Ababouch et al. 1991; Silla Santos 1996; Dalgaard et al. 2006; Kanki et al. 20 2007). Other bacterial genera such as Staphylococcus spp., Pseudomonas spp., 21 Aeromonas spp., Plesiomonas shigelloides and Clostridium perfringens have also 22 been implicated in SFP (Hernández-Herrero et al. 1999). Vibrio spp. used not to be 23 considered histamine producers; however there are recent reports on $V$. alginolyticus 24 and V. anguillarum for being weak histamine producers (Actis et al. 1999; Kim et al. 
1 2001). The histamine-producing bacteria are mostly common post-catching

2 contaminants of fish (Hernández-Herrero et al. 1999).

3

4 Customarily in kitchens (either professional or household) the environmental 5 conditions are far from the ideal concerning environmental temperature, preparation

6 time and hygiene. Frequently there is a crucial lag phase from defrosting and taking a

7 tuna loin out of the refrigerator to preparing (cutting in steaks, cubes etc) and cooking

8 it. Furthermore ambient storage temperatures accelerate bacterial growth and since

9 most prolific histamine producers are common food contaminants, high storage 10 temperature and feebly handling procedures can result in the production of histamine 11 at toxic levels.

13 Scombroid or Histamine fish poisoning (SFP, HFP) is one of the most frequently 14 reported intoxications associated with the consumption of fish worldwide. The SFP 15 intoxication is generally related with high levels of histamine in spoiled fish. 16 Histamine, a biogenic amine involved in allergic reactions, is the main toxin involved 17 in SFP and its toxicity is enhanced by the presence of other biogenic amines in foods 18 (Lehane and Olley 2000). Histamine is formed by decarboxylation of histidine, which 19 is found in high levels in the muscle of fish belonging to the Scomberidae and 20 Scomberesocidae families such as tuna, albacore, mackerel and bonito. Still non21 scombroid fish such as mahi-mahi, sardines, pilchards, anchovies, herring and marlin 22 have frequently been implicated in SFP (Taylor 1985; Clifford and Walker 1992).

23 Symptoms of SFP are cardiovascular, gastrointestinal and neurological, 24 including skin rashes, urticaria, oedema, localized inflammation, nausea, vomiting, 25 diarrhea, cramping, hypotension, headaches, palpitations and an oral burning and 
1 blistering sensation (Lehane and Olley 2000; Gillespie et al. 2001). The SFP 2 intoxication has to be differentiated from other food allergies. Manifestation and 3 severity of symptoms may vary according to individual susceptibility, dietary 4 components and medications, such as isoniazid and antimalarials, which may 5 increase susceptibility. The incubation period is short (less than $2 \mathrm{~h}$ from 6 consumption of food) and symptoms usually resolve within a few hours (Lerke et al. 7 1978; Taylor 1986; Lehane and Olley 2000; McLauchlin et al. 2005).

9 Histamine is not inactivated by the usual thermal processes of the contaminated food 10 (freezing, chilling, cooking, canning etc) and the sole prevention is food storage at 11 temperatures below $4^{\circ} \mathrm{C}$ and avoidance of prolonged handling at ambient 12 temperatures. The amount of histamine produced is a function of the fish species, the 13 individual fish and the fish part which is sampled, the time, the temperature and the 14 type and number of bacteria species present. The toxic dose is variable. Recent 15 reviews of the oral toxicity of histamine to humans in different foods concluded that 16 SFP is slight at $8-40 \mathrm{mg}$ total dose, moderate at $>40 \mathrm{mg}$ and severe at $>100 \mathrm{mg}$ 17 (Shalaby 1996; Lehane and Olley 2000). Scoging (1998a) analysed 405 incidents of 18 SFP in the UK and suggested the following classification: $<100 \mathrm{mg} \mathrm{kg}^{-1}$, safe for 19 consumption; $100-500 \mathrm{mg} \mathrm{kg-1}$, mishandled and potentially toxic; $500-1000 \mathrm{mg} \mathrm{kg}^{-1}$, 20 unsatisfactory and probably toxic; $>1000 \mathrm{mg} \mathrm{kg}-1$, toxic and unsafe for consumption. 21 According to the European legislation (Council Directive, 1991) among nine samples 22 from each batch the mean concentration of histamine must not exceed $100 \mathrm{mg} \mathrm{kg}^{-1}$; 23 two samples may have a concentration of histamine of more than $100 \mathrm{mg} \mathrm{kg}-1$ but 24 less than $200 \mathrm{mg} \mathrm{kg}^{-1}$ and no sample may have a concentration of histamine 25 exceeding $200 \mathrm{mg} \mathrm{kg}^{-1}$. 
2 Tuna fish is considered to be susceptible to histamine formation. Fresh tuna has a

3 shelf life of about 11 days from when they are caught when stored at temperature

$4>4^{\circ} \mathrm{C}$ (Anonymous 1997). In recent years there are an augmenting number of

5 incidents of SFP attributed to consumption of fish (mainly tuna) in restaurants

6 (Anonymous 1986; Scoging 1998a; 1998b; Predy 2003; Wu and Chen 2003; Hall

7 2003; Feldman et al. 2005; McLauchlin et al. 2005; Sigmundsdóttir et al. 2005),

8 where high concentrations of histamine are recorded in fish stored at appropriate

9 temperatures but thawed at the usually high room temperatures of the kitchen. Little

10 information is available about the effects of short - term temperature abuse and

11 bacterial flora on histamine production in tuna fish at the end-point (kitchen). The

12 objective of our study was to assess the effect of different temperature regimens,

13 simulating refrigerated storage and short - term temperature abuse, on histamine

14 formation together with the development of histamine forming microflora in tuna

15 steaks and loins, regardless of the temperature treatment they are subjected before

16 they reach a restaurant kitchen. This simulation of malpractices during the

17 preparation of tuna meals at a restaurant kitchen could be helpful to assess the risks

18 for public health and to implement proper control measures. Also an evaluation of the

19 histamine production capability of the different bacteria comprising the microflora of 20 spoiled fish was performed. 
$1 \quad$ Materials and methods

2

\section{Samples}

5 The fish samples used for the trials were 30 tuna loins (Thunnus alalunga) collected

6 by Sampling Officers from consignments landed at Heathrow Airport. Six of the tuna

7 loins were imported from Brazil, 6 from Sri-Lanka, 6 from Maldives, 8 from Indonesia

8 and 4 from Yemen. The specimens were delivered to the Food Safety Microbiology

9 Laboratory (FSML), Central Public Health Laboratory Service (CPHLS) within $6 \mathrm{~h}$

10 after collection. The average weight of the loins was $2.64 \mathrm{~kg}$, ranging from $2.14 \mathrm{~kg}$ to

$113.21 \mathrm{~kg}$. The fresh loins were transported to the laboratory in insulated boxes and

12 reached the laboratory 1 to 2 days post catching. Every effort was made to keep the 13 temperature of storage of fresh loins at $3-4^{\circ} \mathrm{C}$ from the point of collection to the use of 14 the specimens for the temperature abuse trial. 18 of the loins used (loins from Brazil, 15 Sri - Lanka and Maldives) were frozen at the place of origin. They were transported 16 at the laboratory frozen in well insulated boxes and stored until defrosting in a 17 temperature monitored freezer at $-35^{\circ} \mathrm{C}$. All tuna fish samples were skinned and 18 placed into sterile plastic bags prior to any processing. For all samples the histamine 19 and microbiological analysis was performed the day of arrival at the laboratory to 20 ensure good quality of the loins. The temperature abuse trial has taken place one 21 day after the arrival of specimens to the laboratory.

\section{Temperature abuse process}

24 The tuna loins were divided into 3 groups. One group was stored at $3-4^{\circ} \mathrm{C}$ and 25 consisted of 12 frozen $\left(-35^{\circ} \mathrm{C}\right)$ loins, divided into 4 subgroups ( 3 trial subgroups 
1 containing 3 loins each and one control subgroup containing 3 loins). The control

2 subgroup was defrosted at $3-4^{\circ} \mathrm{C}$ and received no further treatment. The rest 3

3 subgroups were defrosted using 3 different regimes: at $3-4^{\circ} \mathrm{C}$ in a temperature

4 monitored refrigerator, at $20^{\circ} \mathrm{C}$ (room temperature) on the lab bench and in a

5 microwave oven (Philips Cooktronic M710, Philips Electronics UK Ltd, UK) according

6 to the manufacturer's instructions. The 3 trial subgroups were temperature abused

7 for $2 \mathrm{~h}$ daily at $20^{\circ} \mathrm{C}$ for 7 consequent days. Histamine concentration and

8 microbiological tests were performed prior to temperature abuse and on the $5^{\text {th }}$ and

$9 \quad 7^{\text {th }}$ day of temperature abuse.

11 The second group of loins was stored at $0-2^{\circ} \mathrm{C}$ in ice inside a temperature monitored

12 refrigerator and consisted of 9 loins $\left(6\right.$ fresh reserved at $3-4^{\circ} \mathrm{C}, 3$ frozen reserved at $1335^{\circ} \mathrm{C}$ ). The 3 out of the 6 fresh loins served as controls and received no further 14 treatment, while the rest 3 fresh loins were temperature abused for $2 \mathrm{~h}$ daily at $30^{\circ} \mathrm{C}$ 15 in a temperature monitored incubator for 12 consequent days. The 3 frozen loins 16 were defrosted at refrigeration temperature $\left(3-4^{\circ} \mathrm{C}\right)$ in a temperature monitored 17 refrigerator. All loins were tested for histamine prior to temperature abuse and on the $184^{\text {th }}, 8^{\text {th }}$ and $12^{\text {th }}$ day of temperature abuse and were microbiologically analyzed prior 19 to temperature abuse and on the $8^{\text {th }}$ and $12^{\text {th }}$ day of temperature abuse.

21 The third group was stored at $6-7^{\circ} \mathrm{C}$ using a cooled incubator (LMS Cooled incubator, 22 model No 303, LMS Ltd, UK) and consisted of 9 loins ( 6 fresh reserved at $3-4^{\circ} \mathrm{C}, 3$ 23 frozen reserved at $-35^{\circ} \mathrm{C}$ ) divided into 3 subgroups. One subgroup of 3 fresh loins 24 served as control and received no further treatment, while the other subgroup of 3 25 fresh loins was temperature abused for $2 \mathrm{~h}$ daily at $30^{\circ} \mathrm{C}$ in a temperature monitored 


\section{1}

1 incubator for 12 consequent days. The subgroup of 3 frozen loins was defrosted at

2 refrigeration temperature in a temperature monitored refrigerator. Histamine

3 concentration was tested prior to abuse and on the $4^{\text {th }}, 8^{\text {th }}$ and $12^{\text {th }}$ day of

4 temperature abuse, while microbiological analysis was performed prior to abuse and

5 on the $8^{\text {th }}$ and $12^{\text {th }}$ day of temperature abuse. The temperature abuse conditions are

6 concisely presented in Table 1.

\section{Sampling for microbiological and histamine analysis}

9 Sampling for microbiological and histamine analysis was carried out from the surface

10 of the middle part of the loin, from $\sim 1 \mathrm{~cm}$ depth, by cutting aseptically a vertical strip

11 weighing at least $30 \mathrm{~g}$. The sample was homogenized in a laboratory blender (MSE

12 Atomix). $10 \mathrm{~g}$ were used for the microbiological analyses and $10 \mathrm{~g}$ for the histamine 13 analysis. Samples during the temperature abuse trial were taken from almost 14 adjacent areas so as to ensure uniformity in initial histamine content and microbial populations.

\section{Microbiological analysis}

\section{Bacterial enumeration}

19 Bacterial counts were restricted to routinely detected food contaminants, which are 20 also supposed to be histamine producers (Enterobacteriaceae, Pseudomonas spp., 21 Staphylococcus spp., sulfite reducing bacteria, lactic acid bacteria, Photobacterium 22 spp. and Vibrio spp.) and was carried out in standard selective media. Ten grams of 23 homogenized muscle was combined with $90 \mathrm{ml}$ of maximum recovery diluent and 24 ten-fold serial dilutions were performed. For surface plating $0.1 \mathrm{ml}$ of each dilution 25 was used and for pour plating $1 \mathrm{ml}$ of each dilution was used. 
2 Aerobic colony counts (ACC) were determined on Plate Count Agar using surface

3 plating after incubation for 2 days at $30^{\circ} \mathrm{C}$. Enterobacteriaceae, were determined on

4 MacConkey agar No.3 using surface plating after incubation for 1 day at $37^{\circ} \mathrm{C}$.

5 MacConkey agar No.3 permits the growth of other bacteria, so the estimated counts

6 should be considered as presumptive Enterobacteriaceae. Staphylococcus spp. were

7 determined on Baird-Parker agar with egg yolk-tellurite supplement by surface plating

8 after incubation at $37^{\circ} \mathrm{C}$ for 2 days. Characteristic colonies were tested for catalase

9 and coagulase production (Staphytect plus, Oxoid Ltd, Hampshire, England).

10 Pseudomonas spp. were determined using Pseudomonas selective agar

11 supplemented with Cetrimide $\left(10 \mathrm{mg} \mathrm{l}^{-1}\right)$ - Fucidin $\left(10 \mathrm{mg} \mathrm{l}^{-1}\right)$ - Cephaloridine (50

$12 \mathrm{mg} \mathrm{l}^{-1}$ ) by surface plating after incubation for 2 days at $30^{\circ} \mathrm{C}$. Characteristic colonies 13 were confirmed as Pseudomonas spp. by testing for oxidase production with the use 14 of oxidase identification sticks (Oxoid Ltd, Hampshire, England). Sulfite reducing 15 bacteria (SRB) were determined on Tryptose Sulfite Cycloserine agar supplemented 16 with Perfringens (TSC) selective supplement (D-cycloserine $400 \mathrm{mg} \mathrm{I}^{-1}$; Oxoid Ltd, 17 Hampshire, England) using a pour plate with an overlay after incubation for 2 days at $1837^{\circ} \mathrm{C}$ in an anaerobic cabinet (Modular Atmosphere Controlled System, Don Whitley 19 Scientific Ltd, West Yorkshire, UK). Lactic acid bacteria (LAB) were determined on 20 DeMan-Rogosa-Sharpe agar by surface plating after incubation for 3 days at $37^{\circ} \mathrm{C}$ in 21 an anaerobic cabinet. For the determination of Vibrio spp. and Photobacterium spp. 22 ten fold serial dilutions were prepared in Alkaline peptone water (APW). 0,1 ml of 23 each dilution was plated on Thiosulphate Citrate Bile - salt Sucrose (TCBS) agar and 24 incubated at $37^{\circ} \mathrm{C}$ for $24 \mathrm{~h}$ for the detection of Vibrio spp. and $20^{\circ} \mathrm{C}$ for $48 \mathrm{~h}$ for the 25 detection of Photobacterium spp. (Holt et al, 1994). In addition, Gram staining 
1 prepared from randomly selected colonies was performed. The methodology followed

2 is described by Roberts et al. (1995). All media and broths were supplied by the

3 PHLS Media Department (CPHLS Media Department, Colindale, London, UK) (ISO

49002 standard) and were quality controlled by the Media Department Quality Control 5 to UKAS standards.

\section{$7 \quad$ Isolation of bacteria}

8 Characteristic colonies were picked from the selective media used and were

9 characterized to the genus level. All isolates were pure cultured and characterized 10 Gram stain was performed so as to test culture purity and the morphology of the 11 isolates.

13 The identification of the bacteria isolated from MacConkey agar was carried out with 14 the use of the API 20 E system (20 100, BioMérieux, Marcy-l'Etoile, France). The 15 tests used for the identification of Staphylococcus spp. were the catalase test, the 16 coagulase test (Staphytect plus, DR850M, Oxoid Ltd, Hampshire, England), the 17 DNAse production test (DNAase agar, Scharlau Chemie S.A., Sentmenat, Barcelona, 18 Spain), the ability of the isolates to grow in Nutrient agar (Scharlau Chemie S.A., 19 Sentmenat, Barcelona, Spain) supplemented with $7,5 \% \mathrm{NaCl}$ and $10 \% \mathrm{NaCl}$ and the 20 API 20 STAPH system (20 500, BioMérieux, Marcy-l'Etoile, France). Pseudomonas 21 spp. were identified according to their ability to produce oxidase (oxidase 22 identification sticks, BR64A, Oxoid Ltd, Hampshire, England) and with the use of the 23 API 20 NE system (20 050, BioMérieux, Marcy-l'Etoile, France). The identification of 24 Vibrio spp. and Photobacterium spp. was carried out with the use of the oxidase test, 25 the catalase test (Hydrogen peroxide 30\%, analysis grade, 107209 Merck KgaA, 
1 Darmstadt, Germany), the inhibitory effect of the vibriostatic agent 0129 (10 $\mu \mathrm{g}$,

2 DD14 and $150 \mu \mathrm{g}$, DD15, Oxoid Ltd, Hampshire, England and the use of the API

3 20NE system (20 050, BioMérieux, Marcy-l'Etoile, France).

4

5 The bacterial isolates were stored until the examination of their histamine production

6 ability in beads of the Microbank system (ProLab Diagnostics, Ontario, Canada)

7

$8 \quad$ Histamine production by bacterial isolates

9 The ability of the isolated bacteria to produce histamine was measured in the culture 10 supernatant of Møller decarboxylase broth (MD broth) (Atlas, 1995). Prior to the 11 inoculation in MD broth the isolates were inoculated to Trypticase Soy broth 12 containing histidine (TSBH).

TSBH was prepared by addition of $30 \mathrm{~g}$ of Tryptone soy broth (Tryptone Soya Broth (U.S.P.) CM0876, Oxoid Ltd, Wade Road, Basingstoke, UK), $1 \mathrm{~g}$ of histidine (L16 Histidine dihydrochloride, Sigma - Aldrich) in 1 I of deionized water. The $\mathrm{pH}$ of TSBH 17 was adjusted to $\mathrm{pH} 6.8$ before autoclaving for $10 \mathrm{~min}$ at $121^{\circ} \mathrm{C}$.

The composition of MD broth was tryptone 0,5\% (EZMix Tryptone, T-2559, 19 Sigma Chemical Co, St. Louis, USA), beef extract 0,5\% (B-4888, Sigma Chemical 20 Co, St. Louis, USA), glucose 0,05\% (a-D-Glucose analytical grade, 17023051, 21 SERVA Electrophoresis GmbH, Heidelberg, Germany), bromocresol purple 0,001\% 22 (1.03025, Merck KgaA, Darmstadt, Germany), cresol red 0,0005\% (11,447,2, Aldrich 23 Chemical Co, Milwaukee, USA), pyridoxal phosphate 0,0005\% (pyridoxal 5'24 phosphate, P-9255, Sigma) and histidine 1\%. The $\mathrm{pH}$ of MD broth was adjusted to $25 \mathrm{pH} 6.0$ before autoclaving for $15 \mathrm{~min}$ at $121^{\circ} \mathrm{C}$. 
2 The isolates were inoculated in TSBH and incubated at $37^{\circ} \mathrm{C}$ for $24 \mathrm{~h} .100 \mu \mathrm{l}$ of the

3 culture was inoculated in MD broth containing $1 \%$ histidine and incubated at $37^{\circ} \mathrm{C}$ for

$448 \mathrm{~h}$. After $48 \mathrm{~h}$ the culture supernatant was collected and centrifuged 2 times at $53500 \mathrm{mg} \mathrm{kg-1}$ in a desktop centrifuge (Sorvall GLC-4, Sorvall Instruments, 6 Wilmington, DE, USA). The supernatant was sterilized with the use of Acrodisc 7 syringe filters $0.45 \mu \mathrm{m}$ (Pall, New York, USA). The filtered culture supernatants were 8 stored at $-85^{\circ} \mathrm{C}$ until histamine analysis.

\section{Histamine analysis}

11 For the histamine analysis of tuna a fluorometric method was performed as described 12 by Taylor (1978). $10 \mathrm{~g}$ of fish flesh were mixed with $50 \mathrm{ml}$ methanol (822283, Merck $13 \mathrm{KgaA}$, Darmstadt, Germany)and were incubated at $60^{\circ} \mathrm{C}$ in a water bath (type W760, 14 Memmert GmbH, Schwabach, Germany) for $15 \mathrm{~min} .6 \mathrm{ml}$ of water saturated butanol 15 (101990, Merck KgaA, Darmstadt, Germany), $2 \mathrm{~g}$ of sodium carbonate decahydrate 16 (106391, Merck KgaA, Darmstadt, Germany) and $1 \mathrm{ml}$ of $5 \mathrm{M} \mathrm{NaOH}$ (Sodium 17 hydroxide granulated, 106469, Merck KgaA, Darmstadt, Germany) was added to the 18 properly diluted methanol extract of the fish flesh. The tubes were shaken and were 19 allowed to settle. $3 \mathrm{ml}$ of the organic phase was mixed with $3 \mathrm{ml}$ of $0.1 \mathrm{M} \mathrm{HCl}$ 20 (320331, ACS reagent 37\%, Aldrich Chemical Co, Milwaukee, USA). The organic 21 phase was discarded. $0.4 \mathrm{ml}$ of $1 \mathrm{M} \mathrm{NaOH}$ and $0.1 \mathrm{ml}$ of $1 \%$ o-phthalaldehyde ( $P$ 22 0657, Sigma Chemical Co, St. Louis, USA) were added and fluorescent output was 23 measured by a fluorimeter (Kontron M25, Kontron Analytical, Kontron Instruments 24 Ltd, Herts, UK) at $360 \mathrm{~nm}$ excitation and $450 \mathrm{~nm}$ emission wavelengths. Histamine 
1 concentration levels were measured prior to any procedure and after time-

2 temperature abuse of the samples.

3

4 For the histamine analysis of culture supernatants a commercial ELISA kit for the in-

5 vitro diagnostic quantitative determination of histamine in human plasma and urine

6 and in cell culture supernatants was used (Histamine ELISA, RE 592 21, IBL-

7 Hamburg GmbH, Hamburg, Germany). Histamine analysis was performed according

8 to the manufacturer's instructions.

9

10 Prior to histamine analysis of culture supernatants, a validation of the kit was 11 performed. 5 sterile spiked samples of the broth containing different histamine 12 concentrations $(0,5,20,50$ and $100 \mathrm{mg} \mathrm{kg}-1)$ were analysed five times. The results 13 were sufficient for the use of this kit in the measurement of histamine in culture 14 supernatants. A plot of the measured histamine concentration against the actual 15 histamine concentration was drawn. The regression factor of the measured histamine 16 was $r^{2}=0,982$ and the difference between the measured and the actual 17 concentration of histamine did not exceed 2 standard deviations. These results were 18 judged as adequate for the employment of this method in the measurement of 19 histamine in MD broth supernatants.

21 Statistical analysis

22 The two-sided student t-test was used. Descriptive statistics of means, standard 23 deviation and standard error were applied in analyzing the results. A significance 24 level of $5 \%$ was used. The regression analysis between histamine concentration and 25 bacterial counts was contacted by plotting scattered graphs and calculating the $r^{2}$ 
1 factors. $r^{2}$ factors higher than 0.5 were accepted to indicate a correlation between the

2 histamine concentration and the bacterial counts measured.

3

4 Results

$5 \quad$ Temperature abuse

6 The histamine concentrations of the tuna samples upon delivery were ranging from 1

$7 \mathrm{mg} \mathrm{kg}-1$ to $47.1 \mathrm{mg} \mathrm{kg}-1$. The histamine concentrations of the tuna during the time-

8 temperature abuse procedure are presented in Tables $2-4$.

9

10 In defrosted loins stored at $3-4^{\circ} \mathrm{C}$, histamine concentrations were low $(<60 \mathrm{mg} \mathrm{kg}-1)$

11 both in controls and loins abused daily at $20^{\circ} \mathrm{C}$ for $2 \mathrm{~h}$ (Table 2), with only one 12 abused frozen loin exceeding this level (127.4 mg kg-1). There were only minor 13 differences between the different defrosting regimes, and all loins were characterized 14 according to their histamine content as safe for consumption at the end of the abuse 15 procedure.

17 In loins stored at $0-2^{\circ} \mathrm{C}$ the histamine concentration was low $(<70 \mathrm{mg} \mathrm{kg}-1)$ both in 18 controls and defrosted loins abused daily at $30^{\circ} \mathrm{C}$ for $2 \mathrm{~h}$. Higher concentrations (67$19382 \mathrm{mg} \mathrm{kg}-1$ ) were measured in fresh loins abused daily at $30^{\circ} \mathrm{C}$ for $2 \mathrm{~h}$ (Table 3 ). 20 However, the increase was not statistically significant $(p>0.10)$ and at the end of the 21 abuse procedure the controls and defrosted loins were characterized safe for 22 consumption whereas fresh loins were potentially toxic.

24 In loins stored at $6-7^{\circ} \mathrm{C}$ there was a significant increase $(p<0.05)$ in histamine levels 25 in the controls, resulting in final concentrations of $228.3-584.2 \mathrm{mg} \mathrm{kg}-1$ (Table 4). 
1 The final concentration of histamine in defrosted loins abused daily at $30^{\circ} \mathrm{C}$ for $2 \mathrm{~h}$

2 (124.7-2435.8 mg kg-1) was higher than the histamine concentration of the controls.

3 In fresh temperature-abused loins, histamine increased to final concentrations 544.5-

$4 \quad 4156.6 \mathrm{mg} \mathrm{kg}-1$. At the end of the abuse procedure, both the controls and the

5 temperature abused loins were characterized as unsuitable for consumption, while

6 temperature - abused fresh loins being highly toxic.

7

8 No Vibrio spp. and Photobacterium spp. counts were recorded and no strains of

9 these species were isolated, although cultures of these species were performed 10 throughout the experimentations. In temperature abused loins and controls stored at $113-4^{\circ} \mathrm{C}$ (Table 2) the counts of Enterobacteriaceae and coliforms increased by $2.5-$ $123.2 \log _{10}$ and $2.1-2.8 \log _{10}$ respectively whereas the ACC, LAB and Pseudomonas 13 spp. counts increased by approximately $3 \log _{10}\left(2.7-4.5 \log _{10}, 3.1-5 \log _{10}\right.$ and $1.5-$ $145.7 \log _{10}$ respectively) after seven days of storage. However, minimal changes were 15 observed $n$ the counts $f$ SRB in this group of tuna loins.

17 In temperature abused loins and controls stored at $0-2^{\circ} \mathrm{C}$ (Table 3 ), the counts of

18 Enterobacteriaceae and coliforms increased by approximately $2 \log _{10}\left(1.9-2.7 \log _{10}\right.$ 19 and 1.1-2.4 $\log _{10}$ respectively). The ACC, Staphylococcus spp., LAB and 20 Pseudomonas spp. counts increased by 1.4-2.6 $\log _{10}, 2-4.4 \log _{10}$ and $2.2-2.3 \log _{10}$ 21 respectively. In this group of abused tuna loins an increase of almost $1 \log 10$ was 22 observed in the counts of SRB. There was no difference in counts between controls 23 and temperature-abused loins. 
1 In temperature abused loins and controls stored at $6-7^{\circ} \mathrm{C}$ (Table 4), the

2 Enterobacteriaceae and coliforms counts increased by the end of the procedure by

3 approximately $3 \log 10$ ( $3.2 \log _{10}$ and $3.5 \log _{10}$ respectively) in the loins and by $1 \log _{10}$

4 in the controls. Also an increase was observed in ACC and Staphylococcus spp.

5 counts (3-4.1 $\left.\log _{10}\right)$ LAB (2.6-3.4 $\left.\log _{10}\right)$ and Pseudomonas spp. (2.5-5.5 $\left.\log _{10}\right)$.

7 Regression analysis of histamine concentrations and bacterial counts of loins stored

8 at $6-7^{\circ} \mathrm{C}$ revealed correlation between histamine concentrations and aerobic colony

9 counts $\left(r^{2}=0.84\right)$, Enterobacteriaceae counts $\left(r^{2}=0.86\right)$ and coliform counts $\left(r^{2}=0.87\right)$

10 (Figure 1). A correlation between histamine concentrations and aerobic colony 11 counts $\left(r^{2}=0.81\right)$, Enterobacteriaceae counts $\left(r^{2}=0.67\right)$ and coliform counts $\left(r^{2}=0.62\right)$ 12 was also observed in loins stored at $3-4^{\circ} \mathrm{C}$ (Figure 1), whereas in loins stored at $0-$ $13 \quad 2^{\mathrm{O}} \mathrm{C}$ no correlation was observed between histamine concentrations and bacterial 14 counts (Figure 1).

\section{Bacterial isolates and their potential for histamine production}

1777 isolates were isolated from temperature abused loins with high histamine 18 concentration. The isolates are shown in Table 5. Forty of them belong to 19 Enterobacteriaceae (53\% of the total isolated bacteria). These bacteria belong to the 20 species Citrobacter spp. (22\% of Enterobacteriaceae), Enterobacter spp. (20\%), 21 Klebsiella spp. (15\%), Morganella spp. (10\%) and Escherichia spp. (10\%). The 22 Staphylococci that were isolated represent $21 \%$ of the total bacteria isolated and 23 consisted of Staphylococcus xylosus (24\% of Staphylococci), S. epidermidis (19\%), 24 S. hominis (19\%), S. aureus (5\%), S. auricularis $(5 \%)$ kaı S. simulans $(5 \%)$. The 25 Gram negative rods represented $21 \%$ of the total bacteria isolated and consisted of 
1 Pseudomonas fluorescens (29\% of Gram negative rods), Pseudomonas putida 2 (24\%) Burkholderia cepacia (5\%), Flavimonas oryzihabitans (5\%) and Pseudomonas 3 aeruginosa (5\%).

4

5 Morganella morganii was the most active histamine producing species among the 6 bacteria isolated. In the cultures of the three out of four $M$. morganii the 7 concentrations of histamine were 24499,6875 and $6296 \mathrm{mg} \mathrm{kg}-1$, with the 8 concentration of $24499 \mathrm{mg} \mathrm{kg}-1$ being the highest measured among the tested 9 bacterial cultures. High concentrations of histamine were also measured in the 10 cultures of one Staphylococcus hominis isolate (3050 mg kg-1), one Enterococcus 11 hirae isolate (2404 mg kg-1) and two Klebsiella oxytoca isolates (2156 and $2149 \mathrm{mg}$ $12 \mathrm{~kg}-1$ respectively). It should be noted that the four out of five $S$. hominis isolates 13 tested did not exhibit histamine production ability. The histamine concentration of the 14 culture supernatants of the bacterial isolates tested is shown in Table 5. 


\section{Discussion}

2

3 According to our results the temperature of abuse is the most important factor in

4 histamine formation (Tables 2, 3, 4 and Figure 1). The loins abused at $20^{\circ} \mathrm{C}$ (storage

5 at $3-4^{\circ} \mathrm{C}$ ) showed no increase in histamine, while the loins abused at $30^{\circ} \mathrm{C}$ (storage

6 at $0-2^{\circ} \mathrm{C}$ ) presented toxic histamine levels. Histamine concentrations similar to those

7 observed in the present study have been reported by Guizani et al. (2005) in 8 yellowfin tuna. The histamine concentration in yellowfin tuna stored at $8^{\circ} \mathrm{C}$ was 150

9 mg kg-1 after 8 days of storage and in our study it was $147.3 \mathrm{mg} \mathrm{kg}-1$ after 8 days of 10 storage. Our results coincide with those of Kim and Price (1999), who detected low 11 concentrations of histamine $(80 \mathrm{mg} \mathrm{kg}-1)$ in albacore loins stored at $0^{\circ} \mathrm{C}$ for 18 days. 12 Lòpez-Sabater et al. (1996) detected histamine in large tuna fish pieces from the $4^{\text {th }}$ 13 day of storage at $8^{\circ} \mathrm{C}$, measuring concentrations $>2500 \mathrm{mg} \mathrm{kg}-1$ after 6 days of 14 storage at $8^{\circ} \mathrm{C}$, but no histamine was detected in large tuna fish pieces after 12 days at $0^{\circ} \mathrm{C}$. Frank and Yoshinaga (1987) reported histamine concentrations $3.8 \mathrm{mg} \mathrm{kg}-1$,

$165.6 \mathrm{mg} \mathrm{kg}-1$ and $169 \mathrm{mg} \mathrm{kg}-1$ in skipjack tuna loins stored at $-1^{\circ} \mathrm{C}, 4.4^{\circ} \mathrm{C}$ and $10^{\circ} \mathrm{C}$ 17 respectively after 12 to 14 days of storage, which are lower than our measurements 18 obtained under similar conditions; however, the initial histamine concentration 19 measured in the loins by Frank and Yoshinaga was only $1.1 \mathrm{mg} \mathrm{kg}-1$, while in our 20 loins ranged from $1-47.1 \mathrm{mg} \mathrm{kg}-1$. In our study histamine concentrations in control 21 loins stored at $0-2^{\circ} \mathrm{C}$ were similar to those reported in mackerel stored in ice 22 (Bennour et al. 1991). In Spanish mackerel stored at $0^{\circ} \mathrm{C}$, histamine concentrations 23 were lower (mean<6 mg kg-1) (Middlebrook et al. 1988). 
1 In our study, histamine concentration was higher in fresh than in defrosted tuna loins,

2 although the difference was not statistically significant $(p>0.05)$. The freeze -

3 defrosting process appears to reduce the bacterial cell numbers or causes sub-lethal

4 injuries to bacterial cells causing poor histamine production. Baranowski et al. (1990)

5 observed that the duration of freezing of fish is an important factor for histamine

6 formation during storage of mahi-mahi fish at $32^{\circ} \mathrm{C}$ for 1 day. Ben-Gigirey et al.

7 (1998) reported that the survival of bacteria involved in biogenic amine formation is

8 poor at freezing temperatures. Recently Dalgaard et al. (2006) evaluated the

9 biogenic amine formation and microbial spoilage in fresh and thawed chilled garfish,

10 concluding that histamine formation depends strongly on previous freezing of the 11 fish, which probably kills freeze - sensitive bacteria like Photobacterium spp. or 12 Vibrio spp. In our study no Photobacterium spp. or Vibrio spp bacteria were isolated.

13 Taylor and Speckhard (1983) reported that histamine-producing bacteria could not be 14 isolated from frozen tuna without using a $24 \mathrm{~h}$ recovery period. When Staruszkiewicz 15 et al. (2004) studied the changes in selected biogenic amines in mahi-mahi and tuna 16 held in seawater at 25 to $35^{\circ} \mathrm{C}$ for up to $18 \mathrm{~h}$, they observed that histidine 17 decarboxylase activity was retained in some frozen fish samples and could result in 18 further increases in histamine on thawing.

20 According to our results (Tables 2, 3, 4 and Figure 1) the daily abuse of tuna 21 triggered the growth of bacteria. The correlation observed between histamine 22 concentration, ACC, Enterobacteriacae and coliform counts indicate that bacteria 23 belonging to these groups are responsible for histamine production in tuna loins 24 stored at temperatures $>3^{\circ} \mathrm{C}$. Our results coincide with the statement by Stratton and 25 Taylor (1991) that enteric bacteria, specifically Morganella morganii, Klebsiella 
1 pneumoniae and Hafnia alvei are the most prolific histamine producers in fish when

2 they are maintained at temperatures $\geq 4^{\circ} \mathrm{C}$. The Morganella morganii isolates (Table

3 5) varied in their capacity of producing histamine; isolate M4 was the most prolific

4 histamine producer (24 $499 \mathrm{mg} \mathrm{kg}-1$ ), while isolate M1 was a limited histamine

5 producer $(20 \mathrm{mg} \mathrm{kg}-1)$. Other researchers reported $M$. morganii as the most active

6 histamine producer (Frank et al. 1985; Ababouch et al. 1991; López - Sabater et al.

7 1994; Dalgaard et al. 2006). Histamine - producing K. oxytoca strains have been

8 reported by López - Sabater et al. (1994), Rodriguez - Herez et al. (1994) and

9 Hernández - Herrero et al. (1999). Our K. pneumoniae strains produced no

10 detectable amounts of histamine. According to Taylor et al. (1979) Klebsiella

11 pneumoniae is capable of able histamine production, but Kanki et al. (2002) assume 12 that Taylor (1979) has mistakenly attributed histamine production to Klebsiella 13 pneumoniae, misidentifying strains of Raoultella planticola.

15 No correlation was found in loins stored at $0-2^{\circ} \mathrm{C}$, with none of the tested bacterial 16 counts revealing any correlation with histamine production and probably, in this group 17 of loins, another bacterial group was responsible for the production of histamine. 18 Okuzumi et al. (1981) have reported that Psychrophiles and especially halophilic N19 group bacteria growing at $5^{\circ} \mathrm{C}$ can produce histamine. By the end of temperature 20 abuse trials, the dominant microbial populations were LAB followed by the 21 Enterobacteriaceae. Similar results have been reported by Yoshinaga and Frank 22 (1982) and López-Sabater et al. (1996) when large fresh tuna fillets were examined.

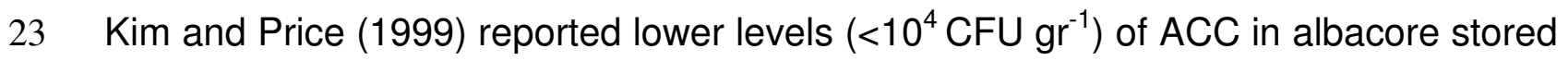
24 in ice, but the temperature of storage was $15^{\circ} \mathrm{C}$. Koutsoumanis et al. (1999) also 25 reported predominance of LAB and Enterobacteriaceae in steaks of Sparus aurata 
1 stored at $0^{\circ} \mathrm{C}$ and $8^{\circ} \mathrm{C}$. In our study the SRB counts remained low during freezing and

2 storage at low temperatures. This observation may be attributed to the inability of

3 some Clostridia species (e.g. C. perfringens) to grow at temperatures below $15^{\circ} \mathrm{C}$

4 (McClane 1997). Ben-Gigigrey et al. (1998) reported absence of SRB in fresh

5 albacore too. From the Gram positive isolates, only one strain of Staphylococcus

6 hominis (S4) and one strain of Enterococcus hirae (EN2) were active histamine

7 producers. Hernández - Herrero et al. (1999) reported production of histamine by $S$.

8 epidermidis and $S$. capitis isolated from salted fish. Tham (1988) reported production

9 of small amounts of histamine from E. faecalis and E. faecium isolated from cheese.

10 The measured histamine concentration from the EN2 isolate (2404 mg $\mathrm{kg}-1)$ is far 11 higher from the histamine concentration reported by Tham (4 mg $\mathrm{kg}-1)$. The 12 presence of Enterococcus spp. in fish is relatively rare and in most cases is attributed 13 to post - catch contamination (Gram kaı Huss 1996). We observed that the prolific 14 histamine producers presented only $10 \%$ of the isolates, while $39 \%$ were slow 15 producers and $51 \%$ were not histamine producing bacteria. The total histamine 16 produced by the prolific producers $(47.4 \mathrm{mg})$ was almost 100 times more than the 17 histamine produced by the slow histamine producers $(0.43 \mathrm{mg})$, indicating that the 18 contribution of slow histamine producing species to histamine build - up in fish flesh 19 is limited.

21 According to our results the histamine concentration was at toxic levels in tuna 22 samples which were exposed at temperatures $\geq 30^{\circ} \mathrm{C}$ for short periods every day and 23 for longer than 3 days. Considering the public health protection, appropriate storage 24 at $<4^{\circ} \mathrm{C}$ and proper handling of tuna fish is essential for delaying histamine formation 25 and preventing SFP outbreaks. For food safety reasons the environmental 
1 temperature of fish processing facilities should be kept $\operatorname{cool}\left(<20^{\circ} \mathrm{C}\right)$ and exposure to 2 ambient temperatures even for short periods should be avoided. In facilities where 3 temperature control is impossible or inadequate, tuna should be stocked up for 4 shorter periods (less than 12 days). Also, the practice of freezing the tuna prior to 5 storage at fridge temperature can restrain histamine production.

6

7 Acknowledgements

8

9 The authors wish to thank The British Council and the General Secretariat for 10 Research and Technology of the Greek Ministry of Development for financial support 11 of the present study. Also the authors wish to express special thanks to Dr. Diane 12 Roberts for her valuable advice throughout this study, to Mr. Jim Clements and Miss 13 Carla Milman for collection of samples and to all personnel of the Toxins Reference 14 Laboratory at Food Safety Microbiology Laboratory, CPHLS for their assistance. 


\section{References}

2

3 Ababouch L, Afilal ME, Rhafiri S, Busta FF, 1991. Identification of histamine 4 producing bacteria isolated from sardine (Sardina pilchardus) stored in ice and at ambient temperature $\left(25^{\circ} \mathrm{C}\right)$. Food Microbiology 8: $127-136$.

Actis, LA, Smoot JC, Barancin CE, Findlay RH, 1999. Comparison of differential plating media and two chromatography techniques for the detection of histamine production in bacteria. Journal of Microbiological Methods 39 (1): $79-90$.

Anonymous, 1986. Epidemiologic Notes and Reports Restaurant-Associated Scombroid Fish Poisoning -- Alabama, Tennessee. Morbidity and mortality weekly report 35 (16): $264-5$.

Anonymous, 1997. Marine biotoxins. Communicable disease report weekly 7: 130.

Baranowski J, Frank H, Brust P, Chongsiriwatana M, Premaratne R, 1990. Decomposition and histamine content in Mahimahi (Coryphaena hippurus). Journal of Food Protection 53: 217-222.

Behling AR, Taylor SL, 1982. Bacterial histamine production as a function of temperature and time of incubation. Journal of Food Science 47: 1311-1314, 1317.

Ben-Gigirey B, Vieites Baptista de Sousa JM, Villa TG, Barros-Velasquez J, 1998. Changes in biogenic amines and microbiological analysis in albacore (Thunnus alalunga) muscle during frozen storage. Journal of Food Protection 61: 608-615.

Bennour M, El Marrakchi A, Bouchriti N, Hamama A, El Quadaa M, 1991. Chemical and microbiological assessments of mackerel (Scomber scombrus) stored in ice. Journal of Food Protection 54: 789 - 792. 
1 Clifford M, Walker R, 1992. The aetiology of scombrotoxicosis. International Journal $2 \quad$ of Food Microbiology 27: $721-724$.

3 Council Directive 91/493/EEC of 22 July 1991 laying down the health conditions for 4 the production and the placing on the market of fishery products.

Dalgaard P. Madsen HL, Samieian N, Emborg J, 2006. Biogenic amine formation and microbial spoilage in chilled garfish (Belone belone belone) - effect of modified atmosphere packaging and previous frozen storage. Journal of Applied Microbiology 101: 80-95.

Emborg J, Dalgaard P, 2006. Formation of histamine and biogenic amines in coldsmoked tuna: an investigation of psychrotolerant bacteria from sampes implicated in cases of histamine fish poisoning. Journal of Food Protection 69 (4): $897-906$.

Feldman KA, Werner SB, Cronan S, Hernandez M, Horvath AR, Lea CS, Au AM, Vugia DJ, 2005. A large outbreak of scombroid fish poisoning associated with eating escolar fish (Lepidocybium flavobrunneum). Epidemiology and Infection 133(1): $29-33$.

Frank HA, Baranowski JD, Chongiriwatana M, Brust PA, Premaratne RJ, 1985. Identification and decarboxylase activities of bacteria isolated from decomposed mahimahi (Coryphaena hippurus) after incubation at 0 and $32^{\circ} \mathrm{C}$. International Journal of Food Microbiology 2: $331-340$.

Frank H, Yoshinaga D, 1987. Table for estimating histamine formation in skipjack tuna, Katsuwonus pelamis, at low nonfreezing temperatures. Marine Fisheries Reviews 49: 67 - 70 . 
1 Gillespie IA, Adak GK, O’Brien SJ, Brett MM, Bolton FJ, 2001. General outbreaks of

2

3

4 5 infectious intestinal disease associated with fish and shellfish, England and Wales, 1992 - 1999. Communicable disease and public health 4: $117-123$.

Gram L, Huss H, 1996. Microbiological spoilage of fish and fish products. International Journal of Food Microbiology 33: 121 - 137.

Guizani N, Al-Busaidy MA, Al-Belushi IM, Mothershaw A, Rahman MS, 2005. The effect of storage temperature on histamine production and the freshness of yellowfin tuna (Thunnus albacares). Food Research International 38: 215-222.

Hall M, 2003.Something fishy: six patients with an unusual cause of food poisoning! Emergency Medicine 15(3): $293-5$.

Hernández-Herrero MM, Roig-Sagués AX, Rodríguez-Jerez JJ, Mora-Ventura MT, 1999. Halotolerant and halophilic histamine-forming bacteria isolated during the ripening of salted anchovies (Engraulis encrasicholus). Journal of Food Protection 62: $509-514$.

Holt J, Krieg N, Sneath P, Staley J, Williams S, editors, 1995. Bergey's manual of determinative bacteriology. Williams \& Wilkins, Baltimore USA, $9^{\text {th }}$ ed.

Joosten H, Northolt M, 1989. Detection, growth and amine - producing capacity of Lactobacilli in cheese. Applied and Environmental Microbiology 55: 2356-2359.

Kanki M, Yoda T, Tsukamoto T, Shibata T, 2002. Klebsiella pneumoniae produces no histamine: Raoultella planticola and Raoultella ornithinolytica strains are histamine producers. Applied and Environmental Microbiology 68: 3462 - 3466.

Kanki M, Yoda T, Tsukamoto T, Baba E, 2007. Histidine Decarboxylases and their Role in Accumulation of Histamine in Tuna and Dried Saury. Applied and Environmental Microbiology Jan 12 (article in press). 
1 Kim SH, An H, Price RJ, 1999. Histamine formation and bacterial spoilage of 2 albacore harvested off the U.S. Northwest coast. Journal of Food Science 64: $340-343$.

4 Kim SH, Ben-Gigerey B, Barros-Velásquez J, Price RJ, An H, 2000. Histamine and 5

Klausen NK, Huss HH, 1987. Growth and histamine production by Morganella morganii under various temperature conditions. International Journal of Food Microbiology 5: $147-156$.

Koutsoumanis K, Lampropoulou K, Nychas GJE, 1999. Biogenic amines and sensory changes associated with the microbial flora of Mediterranean gilt - head sea bream (Sparus aurata) stored aerobically at 0,8 , and $15^{\circ} \mathrm{C}$. Journal of Food Protection 62: $398-402$.

Lehane L, Olley L, 2000. Histamine fish poisoning revisited. International Journal of Food Microbiology 58: $1-37$.

Lerke P, Werner S, Taylor S, 1978. Scombroid poisoning - report of an outbreak. The Western journal of medicine 129: $381-386$.

López - Sabater El, Rodríguez - Jerez JJ, Hernández - Herrero M, Mora - Ventura MT, 1994. Bacteriological quality of tuna fish (Thynnus thynnus) destined for canning: effect of tuna handling on presence of histidine decarboxylase bacteria and histamine level. Journal of Food Protection 57: 318 - 323. 
1 Lòpez-Sabater El, Rodríguez-Jerez JJ, Hernández-Herrero M, Roig-Sagués AX, Mora-Ventura MT, 1996. Sensory quality and histamine formation during controlled decomposition of tuna (Thunnus thynnus). Journal of Food Protection 57: $167-174$.

McClane B, 1997. Clostridium perfringens. In: Doyle MP, Beauchat LR, Montville TJ, editors. Food Microbiology: Fundamentals and Frontiers. ASM Press, Washington D.C., pp. $305-326$.

McLauchlin J, Little CL, Grant KA, Mithani V, 2005. Scombrotoxic fish poisoning. Journal of Public Health 28: 61 - 62.

Middlebrook BL, Toom PM, Douglas WL, Harrison RE, McDowell S, 1988. Effects of storage time and temperature on the microflora and amine development in Spanish mackerel (Scomberomorus maculatus). Journal of Food Science 53: $1024-1029$.

Okuzumi M, Okuda S, Awano M, 1981. Isolation of psychrophilic and halophilic histamine-forming bacteria from Scomber japonicus. Bulletin of the Japanese Society of Scientific Fisheries 47: $1591-1598$.

Predy G, Honish L, Hohn W, Jones S, 2003. Was it something she ate? Case report and discussion of scombroid poisoning. Canadian Medical Association Journal 168 (5): $587-8$.

Roberts D, Hooper D, Greenwood M, 1995. Practical Food Microbiology. Public Health Laboratory Service, London.

Rodriguez- Jerez JJ, Lopez-Sabater El, Roig-Sagues AX, Mora-Ventura MT, 1994. Histamine, cadaverine and putrescine forming bacteria from ripened Spanish semipreserved anchovies. Journal of Food Science 59: 998 - 1001. 
1 Scoging AS, 1998. Scombrotoxic (histamine) fish poisoning in the United Kingdom: 1978 to 1996. Communicable disease and public health 1: $204-205$.

3 Scoging AS, 1998. Marine biotoxins. Journal of Applied Microbiology 84 (S1): 41 S 4 $50 S$. Food Research International 29: 675 - 690.

Sigmundsdóttir G, Magnússon S, Ingólfsson R, Porvaldsdóttir IR, Haraldsdóttir V, Gíslason D, 2005. Scombroid Poisoning at an Icelandic Restaurant. Læknablaŏiŏ 91: 251 - 3.

Silla Santos MH, 1996. Biogenic amines: Their importance in food. International Journal of Food Microbiology 29: 213-231.

Staruszkiewicz WF, Barnett JD, Rogers PL, Benner RA, Wong LL, Cook J, 2004. Effects of on-board and dockside handling on the formation of biogenic amines in mahi-mahi (Coryphaena hippurus), skipjack tuna (Katsuwonus pelamis), and yellowfin tuna (Thunnus albacares). Journal of Food Protection 67 (1); $134-41$.

Stratton JE, Taylor SL, 1991. Scombroid poisoning. In: Ward D, Hackney C, editors. Microbiology of Marine Food Products. Spectrum, New York, pp. 331-351.

Taylor S, Lieber E, Leatherwood M, 1978. A simplified method for histamine analysis of foods. Journal of Food Science 43: $247-50$.

Taylor S, Guthertz L, Leatherwood M, Tilman F, Lieber E, 1979. Histamine production by food - borne bacterial species. Journal of Food Safety 1: $173-$ 187.

Taylor S, Speckhard M, 1983. Isolation of histamine - producing bacteria from frozen tuna. Marine Fisheries Reviews 45: 35 - 39. 
1 Taylor SL, 1985. VPH/FOS/ 85.1. Histamine poisoning associated with fish, cheese,

2 and other foods. World Health Organization, Geneva.

3 Taylor S, 1986. Histamine food poisoning: Toxicology and clinical aspects. CRC $4 \quad$ critical reviews in toxicology 17: $91-128$.

5 Tham W, 1988. Histamine formation by enterococci isolated from home - made goat $6 \quad$ cheese. International Journal of Food Microbiology 7: 103 - 108.

7 Wu SF, Chen W, 2003. An outbreak of scombroid fish poisoning in a kindergarten. $8 \quad$ Acta Paediatrica Taiwan 44 (5): $297-9$.

9 Yoshinaga DH, Frank HA, 1982. Histamine-producing bacteria in decomposing 10 skipjack tuna (Katsuwonus pelamis). Applied and Environmental Microbiology $11 \quad 44: 447-452$. 


\section{1}

2

3

\section{Captions}

2

3 Table 1. Temperature abuse conditions.

4 Table 2. Histamine concentrations and bacterial counts in tuna loins stored at $3-4^{\circ} \mathrm{C}$ and abused at $20^{\circ} \mathrm{C}$ [histamine $(\mathrm{mg} \mathrm{kg}-1)$ in average and standard error in brackets, bacterial counts (CFU $\mathrm{gr}^{-1}$ ) in average of $\log _{10}$ and standard error in brackets].

Table 3. Histamine concentrations and microbial counts in fresh and frozen tuna loins stored at $0-2^{\circ} \mathrm{C}$ and abused at $30^{\circ} \mathrm{C}$ [histamine (mg $\mathrm{kg}-1$ ) in average and standard error in brackets, bacterial counts (CFU $\mathrm{gr}^{-1}$ ) in average of $\log _{10}$ and standard error in brackets].

Table 4. Histamine concentrations and microbial counts in fresh and frozen tuna loins stored at $6-7^{\circ} \mathrm{C}$ and abused at $30^{\circ} \mathrm{C}$ [histamine (mg $\mathrm{kg}-1$ ) in average and standard error in brackets, bacterial counts (CFU $\mathrm{gr}^{-1}$ ) in average of $\log _{10}$ and standard error in brackets].

Table 5. Bacterial Isolates and histamine concentration in culture supernatants after incubation at $37^{\circ} \mathrm{C}$ for $48 \mathrm{~h}$.

Fig 1. Regression analysis of histamine and Aerobic Colony Counts, Enterobacteriaceae and Coliforms 